\title{
MORPHOLOGY OF THE LEMNA FROND
}

\author{
FREDERICK H. BLODGETT \\ (WITH PLATE XIV AND ONE FIGURE)
}

In the case of structures simplified by reduction, it is sometimes necessary to trace the development of the parts through their immature stages in order to understand the morphology of the mature individuals. This has especial interest when the normal method of reproduction depends upon the development in rapid succession of vegetative propagules, as in the Lemnaceae. The character of such greatly reduced bodies has been variously interpreted, being regarded as stem, leaf, or both fused together, by different writers; while some use a term like "disklike bodies." Since GRAY ${ }^{I}$ used Lemna as the type of "frondose stem or frond," this name will be used for convenience through the paper. In but few of the articles mentioning the character of the frond has any attempt been made to indicate the basis for the choice of terms, even HegELMaIER ${ }^{2}$ depending largely upon academic argument rather than upon structural details in his discussion of the frond. CALDWELL ${ }^{3}$ devoted most of his attention to the development of the flower parts, and did not attempt more than a review of the general character of the frond as presented by others. In the following notes an effort is made to show what structural units contribute to the formation of the frond and the part taken by each in the development of the successive vegetative individuals.

\section{Inception of frond rudiment}

The Lemna frond is characterized by a sheath or pouch on each side of the base. Within each of these pouches a frond of the next vegetative generation arises, but the two do not develop at the same time. When flowers are produced each one grows in the

${ }^{x}$ GrAy, AsA, Structural botany. New York. 1879 (p. 67).

${ }^{2}$ Hegelmater, F., Die Lemnaceen. Leipzig. 1868.

3 CALDWell, Otis W., Life history of Lemna minor. Bot. Gaz. 27:37-66. i899. 
position in which the frond ordinarily grows, although a young frond may later develop within the same pouch. Behind the growing frond or flower there is a bud normally present. The rudiments of this bud appear very early in the development of the frond, in the axil of which it is located. Such a bud is shown in fig. I. The frond subtending this bud was slightly smaller than that shown on the same scale in fig. Iо. The development of the bud involves only elongation at first (figs. 3 and 4 ), but at an early stage there is a thickening of the basal region. The limitations of space soon force the elongating bud to turn from the nearly erect position to one more or less oblique and finally to the horizontal. This is less rapidly accomplished when the bud lies behind a flower, since in this case the developing seed by its bulk spreads the forward part of the pouch, and leaves immediately behind itself a space in which an erect development of the bud may go on for a considerable time; but even in this case the frond becomes horizontal while still minute.

\section{Differentiation of parts}

When the bud is about twice as long as the diameter of its base, the cells of the root initial may be distinguished. They are usually the fourth cell layer from the ventral surface, and develop a cleavage along the contact region of the third and fourth series of cells (figs. 5 and 8). The cells of the fourth layer and deeper develop the root cap and the root structures within the cap; those of the second and third layers are crushed by the elongation of the root tissue; but the outer layer elongates with the forward growth of the root and forms the "root sheath" which commonly persists about the base of the mature root.

At nearly the same time when the root develops there is formed upon the dorsal surface of the bud a slight elevation or mound of cells. This is nearly opposite the group of root initials and marks the origin of the bud for the next frond in the series (fig. 3). Very soon a second mound is visible, close to the insertion of the bud upon the parent tissue, just behind the bud of the daughter frond (figs. 7 and $7 a$ ). This is the inception of the bud axillary to the frond the development of which is being followed. This bud will 
develop but slowly, as compared with the bud anterior to it, which represents the daughter frond; thus when the latter is as shown in fig. Io, the axillary bud is only as shown in fig. 2 , or in figs. 6 and io.

The next stage marks the beginning of the upper wall of the inclosing pouch by which the bud will be protected until large enough to project beyond the pouch margin. This first appears as a sharp projection just anterior to the bud of the daughter frond, as shown in fig. 6. At first the bud and the protective ridge are both in the median region of the young frond, and nearly opposite the root rudiment; but with the continued growth of all parts, the space available for vertical enlargement becomes insufficient and there is a lateral shifting of the dorsal structures. The bud itself becomes divided into two groups of cells, each a potential growing point. The development of the pouch wall is shifted from the position of a covering which is directed posteriorly over the bud, to that of an outgrowth which is directed obliquely backward from either side of the original position.

A further change follows this shifting of the bud. The overgrowing wall is displaced along with the inclosed bud, and thus there are formed two pouches at the base of the frond. The pouch walls, which are first recognized as a slight ridge anterior to the bud rudiment, extend around this as a flattened ring having its insertion along the side of the elongating base or stem of the frond and laterally on the widening frond. At the ends there is but little projecting growth of this ridge, but from the portion just above and below the inclosed bud a considerable development takes place. The pouch walls merge into the body of the frond completely at their insertion.

A vascular connection remains between the two buds after they are separated by the upward growth of the supporting tissue, as is shown in fig. 9. No distinctly vascular elements are developed at this stage, but the elongated cells here shown are their rudiments. This figure also indicates the unequal development of the opposite buds. In Lemna trisulca there is less difference in development than in most species, but the general sequence of stages is similar. 


\section{Later stages of development}

The young frond now has present all the structural units which will be visible in the mature free frond, the later developments being in the manner of enlargement of parts present and the completion of structures already initiated. The two buds in their respective pouches will follow the same stages as the frond developing from an axillary bud, such as is being discussed; while the root shows little of special interest. Two changes which take place, however, should be mentioned; the rapid elongation of the region anterior to the bud-root region, and the thrusting forward of the whole structure by the development of the basal region into a stalk or stipe. In Lemna this basal region is attached marginally to the main portion of the frond, but in Spirodela it is inserted upon the ventral surface some distance from the edge, and in Wolffia it is almost completely lacking.

The axillary bud which was at first upon the dorsal surface of the stipe is forced into a lateral position, as was the case with the frond bud which was divided. In this case the lateral shifting seems to be due to the more rapid growth of the stipe to one side of the median line, resulting in a tipping of the bud and raising its base as the stipe thickens. In the frond this stage is accompanied by the development of air cavities in the anterior region which is elongating rapidly. The individual cells become highly vacuolated, and the stomata are differentiated. The vascular strands appear at this time in the anterior region, which in all essentials assumes the structural characteristics of a foliage leaf.

The vascular cells in the stipe become more clearly defined as a single strand centrally located in the tissues of the connecting structure. This strand ends in a confused group of cells at the point of origin of the vascular tissues of the root, the lateral buds, and the anterior region. This region corresponds to the mat of vascular elements in the base of a bulb as discussed by CHRYSLER ${ }^{4}$, and may be considered as locating closely the stem apex of the plant. In bulbs the apical region usually gives rise to a single main bud, with some lateral buds axillary to bud scales. In Lemna the

${ }_{4}$ Chrysler, M. A., Development of the central cylinder in Araceae and Liliaceae. Bот. GAZ. $38: 161-184$. 1904 . 
terminal bud is divided by vertical pressure and constraint, and appears as a pair of lateral buds except in the initial stages; but the axillary bud is developed in its normal position, behind the foliar outgrowth.

\section{Homologies of the Lemna frond}

The Lemna frond is a structure of reduced character, especially adapted to vegetative propagation under particular conditions. The two forces which act upon the plant as possible determining factors in the resulting structure are the tension of the water film and the buoyant effect of the liquid. The film tension tends to attenuate in all directions any elastic structure floating upon it, while the upward thrust of buoyancy tends to lift any deep-lying portion into the same plane with the thinner parts. The thin frond responds to the conditions imposed, and may be considered as a result of the forces involved. The roots act as drags or brakes against too free movement in the water, and to return the dorsal surface to the air after the frond has been immersed by any sudden shock, the drag of the projecting roots tending to orient the frond as it rises to the surface by its buoyancy. Inverted plants of Spirodela will thus orient themselves in a 3 -inch dish of water, but complete inversion would but rarely occur under natural conditions.

The runner of Erythronium is a structure also of reduced nature and also developed to meet particular conditions. In this case the forces involved are the outward thrust of growing tissues and the resistance of the surrounding soil. The root type of structure is manifestly best fitted to this condition, having the region of elongation close to the apex of the structure. An investigation of the development of these runners ${ }^{5}$ showed that the zone of elongation is so located, and that the component parts of the runner are adapted to the conditions and factors present, namely, the offsetting of propagules, and their movement through soil. A longitudinal section of a runner is shown in text fig. I (I). The bud scale forming the anterior wall of the hollow tip elongates, as do leaves, by basal growth; the axial portion of the runner which thrusts the terminal bud forward elongates by growth near the tip. The two

${ }^{5}$ BLODGETt, F. H., Origin and development of bulbs in Erythronium. Bot. Gaz. 50:340-372. I910. 
growing regions harmonize completely, and the inclosed bud is thrust forward through the soil, with no serious injury from antagonistic growth forces. The pointed cylinder meets the conditions of progress through a solid medium as does the flat frond for floating upon a fluid surface.

The Lemna frond may be closely compared to the Erythronium runner in structural details. If the outer scale of the terminal
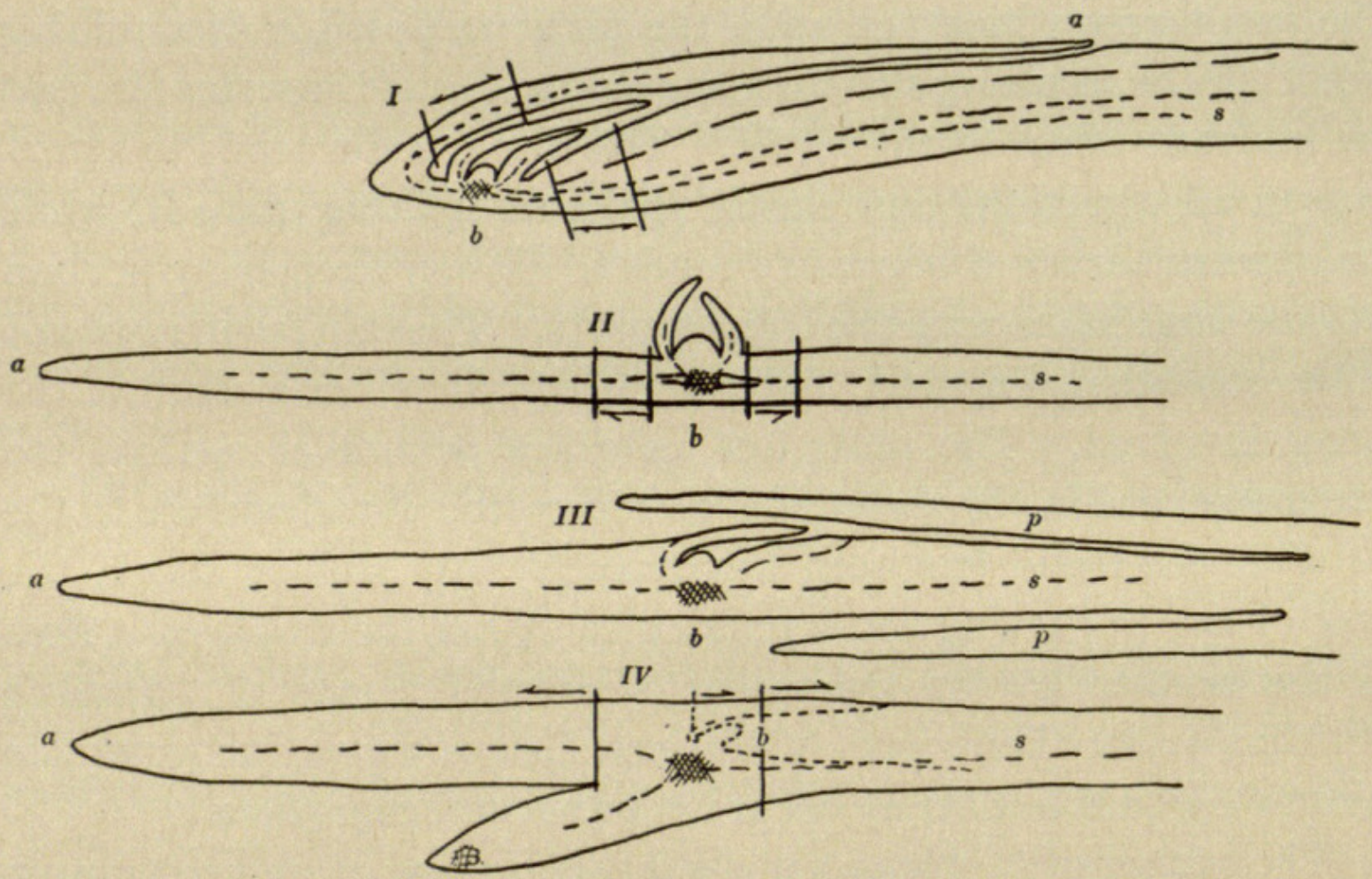

FIG. 1.-Homology of Lemna frond and Erythronium runner: a, tip of first leaf; $b$, stem apex of bud; $s$, shoot axis; $p p$, walls of pouch.

bud of the runner could be turned forward on its base as a hinge, a structure would result of the character shown at II in the text figure. This has a terminal foliar region, a central one from which a dorsal bud and ventral root originate, and a basal stem or cauline region, ${ }^{6}$ but the bud is erect. The growing regions are still at the base of the foliar and near the tip of the cauline portions of the whole. If this were to be formed within a vertically restricted space, the dorsal bud would be flattened, and probably somewhat

${ }^{6}$ These correspond respectively to the "upper internode," the "node," and the "basal internode" of CALDWELL (op. cit., p. 43), and supports his use of the word "shoot"; but the shoot consists of a terminal leaf, a node with bud tissues, and a stem, rather than of an "undifferentiated upper internode" and specially modified "basal and nodal regions." 
fused to adjacent parts (as in III of the text figure), as is the case on the posterior surface of the bud scale in the runner bud shown at I. The vertical thickening of the tissues at the insertion of the bud would tend to split the meristem group of cells so that a pair of lateral buds would finally result, as in the Lemna structure.

The protective inner scale of the bud, which is represented in diagram III as bent backward under the overlying pouch wall, in the Lemna frond shown at IV, is fused with the posterior margin of the foliar tissues of the frond, and laterally to the side of the stem. This pouch wall arises as a ring about the base of the bud which it will finally inclose, and is therefore homologous with the development of the scale leaf about the stem tip of a bulb, or a bud of the Erythronium type. Under the adjustment to space and pressure, the ring is flattened to a narrow eclipse, and is divided by the same conditions as those which divide the bud within.

In the region immediately below the stem apex in bulbs, and the corresponding point in Lemna, the root initials are developed; this region is indicated in the diagrams by cross-hatching, adjacent to $b$ in I, II, III. In Lemna only one root is regularly developed, but in Spirodela several are formed. The activity of the adjacent apical meristem evidently continues for a considerable period, allowing for the successive formation and development of new fronds within the same parent pouch. The old fronds are released by the separation of the cells close to the insertion of the stem upon the parent tissues, apparently by the breaking down of the middle lamella of a band transverse to the stem. The stump left in such a case is seen at $s$ in fig. 2. By the enlargement of the axillary bud this stump will be obliterated before the new frond is far advanced.

\section{Conclusions}

The Lemna frond is a propagative structure consisting of a terminal leaf; a bud inclosed by a flattened bud scale, the base of which is fused to the base of the leaf and laterally to the stem; and an apical region from which new fronds are developed. Two buds are formed through the splitting of a single bud rudiment by vertical pressure during early stages of growth. The frond meets the conditions of a floating habitat in which the tension of the 
surface film apparently is an active factor. Through the lack of space for vertical succession, the several outgrowths from the apical region are liberated as a horizontal series, the overlapping of successive individuals forming an element of confusion in an examination of their structure.

\section{Texas Agricultural Experiment Station \\ College Station, Texas}

\section{EXPLANATION OF PLATE XIV}

FIGS. 1, 2.-Early stages in formation of axillary buds: magnification, indicated by scale of $0.05 \mathrm{~mm}$., uniform for all figures except fig. 9 , which has its special scale indicated.

FIG. 3.-Median section of older bud: $b$, daughter bud rudiment; $a$, axillary bud.

FIg. 4.-Similar section at next stage: buds displaced by thickening of base; $4 a$, details of root from adjacent section.

Fig. 5.-Adjacent sections of bud in axil of nearly grown seed (to left), showing daughter bud and root regions; axillary bud not yet defined; intermediate in age between figs. 2 and 3.

Figs. 6, 7.-Daughter buds from opposite sides of median section shown in fig. $4 ; 7 a$, axillary bud the edge of which shows at $a$ in fig. 7 .

FIG. 8.-Sagittal section of frond, showing origin of inclosing scale leaf or pouch $(p, p)$ about daughter bud $(b)$; below the root is pushing out, and to the right the leaf is elongating.

FIG. 9.-Transverse section through apical region of frond, showing displaced halves of daughter bud, now unequally developed, and connecting cells; compare figs. 2 and 3 ; low power.

FIG. Io.-Young frond in sagittal section: leaf forms right half; basal buds partly inclosed by bud scale or pouch (at Io $a$ and $1 \circ c)$; axillary bud at Io $b$, with edge of buds ( $a$ and $c$ ) and of pouch wall $(p)$. 


\section{$2 \mathrm{BHL}$ Biodiversity Heritage Library}

Blodgett, Frederick H. 1915. "Morphology of the Lemna Frond." Botanical gazette 60(5), 383-390. https://doi.org/10.1086/331676.

View This Item Online: https://www.biodiversitylibrary.org/item/108949

DOI: https://doi.org/10.1086/331676

Permalink: https://www.biodiversitylibrary.org/partpdf/223705

\section{Holding Institution}

Missouri Botanical Garden, Peter H. Raven Library

\section{Sponsored by}

Missouri Botanical Garden

\section{Copyright \& Reuse}

Copyright Status: Public domain. The BHL considers that this work is no longer under copyright protection.

This document was created from content at the Biodiversity Heritage Library, the world's largest open access digital library for biodiversity literature and archives. Visit BHL at https://www.biodiversitylibrary.org. 